\title{
Teaching Activism: Reflections on Developing "Leaders of Tomorrow" through Activist Approaches to Community Service-Learning
}

\author{
Brad Wuetherick
}

\begin{abstract}
Educating leaders of tomorrow" is a common refrain for many in higher education around the world, but what does it mean to educate leaders of tomorrow? What would a curriculum designed to educate leaders look like across disciplines? This article explores leadership, conceptualized as the capacities (knowledge, skills, and attitudes) required for students to act as positive change agents in society, as an attribute we aim to develop in all students. It also calls on educators to consider how community servicelearning grounded in activist pedagogies might provide exceptional opportunities to develop students' capacities to be leaders across the disciplines.
\end{abstract}

KEYWORDS leadership studies, teaching leadership, community service-learning, activist pedagogies

\section{"Here at the University of $X X^{1}$, we educate the leaders of tomorrow."}

The image of a senior administrator addressing a large crowd of students, staff, faculty, or the general public with these or similar words is probably familiar to many in higher education. On its surface it is hard to find fault with this statement. Many post-secondary graduates have gone on to accomplish great things in their professional lives, and many of our current students are capable of accomplishing great things in the future. Of all the institutions that have made this claim, however, few have really explored what it means to educate "leaders of tomorrow," even as there are increased calls for leadership skills as an important educational outcome across higher education (Alvesson \& Spicer, 2012; Komives et al., 2007; Wagner \& Pigza, 2016). What would a curriculum designed to educate leaders look like across the disciplines? When one scratches under the surface of a phrase like "leaders of tomorrow," particularly in the context of what individual academics, departments, and faculties are currently doing to achieve this goal, the simplicity of this concept begins to evaporate. In a rapidly changing higher education context, particularly arising from increasingly neoliberal accountability mechanisms, how is the education of "leaders of tomorrow" realized within higher education?

Rarely are statements about educating leaders of tomorrow followed by any meaningful

\footnotetext{
${ }^{1}$ Here 'XX' could symbolize any university or college in Canada or around the Western world.
} 
exploration of what is meant by leadership. This mirrors a common critique within the field of leadership studies, where it has been argued that the majority of publications do not attempt to define the concept of leadership even as they stress the importance of such definitions to advancing the development of leadership capacities (Alvesson \& Spicer, 2012). Nor have we collectively developed a comprehensive vision of what type of leader we are attempting to educate, or what outcomes might be developed if leadership were a universal graduate attribute for all disciplines. And almost no discussion has occurred within higher education around what the best pedagogies might be to develop such attributes.

What limited institutional discussion has occurred around leadership (particularly as represented by institutional academic plans) is usually couched in language around "global citizenship" and "educating for democracy," both of which are valid goals of higher education and have been explored extensively within the literature, but are not synonymous with leadership as an aim within, and outcome for, higher education. Even when leadership is mentioned as a learning outcome within an institution, rarely is the question asked-to what end and for what purpose? In considering these questions, it is crucial to make explicit the values of the individual academic, the institution, and the broader community as they relate to educating for leadership. As well, we must begin to make explicit why we use the pedagogical approaches we do in relation to the development of leadership attributes.

Informed by research in the field of leadership studies, this paper will explore conceptions of leadership as a universal graduate attribute across the disciplines, in order to consider how we might educate leaders in higher education. In doing so, I argue for a move towards a more activist approach to community service-learning that provides better opportunities for students to engage in reflective practices about their disciplinary learning, the broader needs of the community, and their development of leadership attributes. The goal is to demonstrate that by breaking down barriers (perceived or real) to using activist pedagogies, it is possible to provide meaningful learning experiences to develop authentic leadership capacities through activist community service-learning.

\section{Educating Leaders of Tomorrow}

Barnett (2000) argues that the challenges faced in our $21^{\text {st }}$ century society are "super-complex" by nature. These challenges require students and graduates to be able to traverse, indeed to thrive in, the super-complexity arising from disciplinary, interdisciplinary, multi-disciplinary, and trans-disciplinary ways of thinking, understanding, acting, and being in the world (Barnett, 2010). How, then, do we shape our educational experiences to develop future leaders, or is it enough that it is an exciting side effect of educating the best and brightest? And is the goal of educating "leaders of tomorrow" an intended outcome for the best of our students, or is it meant to be a goal for all of our students? The problem begins with the realization that the vast majority of universities and colleges who use phrases like "educating leaders of tomorrow" have left unsaid what they mean by leader or by leadership.

There is an implicit understanding that future alumni will become accomplished researchers and educators, successful community and business leaders, or elected officials of local to 
national governments. The University of Alberta in Canada, to give one example, often celebrates a former Canadian prime minister, a chief justice of the Supreme Court of Canada, well-known actors or media personalities, and Nobel laureates whom they count among their alumni. The discussion of educating leaders of tomorrow, however, is dependent on what is meant by the word leadership. If you were to ask a number of people, particularly among academics, what leadership is or to describe a "leader," you would likely receive back just as many different answers.

As part of a research project on leadership, I gathered over fifty open-ended qualitative responses from workshop participants about what "educating leaders of tomorrow" means to them in higher education (Wuetherick, 2007). The participants gave informed consent for their responses to be used as part of an ongoing research project on leadership as a graduate attribute across the disciplines. The responses received from these participants can be grouped into three broad themes. First (and by far the most common), the responses articulate a vision of students becoming effective, global citizens. A representative example is: "Students should graduate ready to contribute to society as global citizens." Second, the responses articulated the types of attributes or skills "leaders" might need, including such things as conflict resolution, communication, and problem-solving. A representative example is:

[Higher education should] help students acquire the skills needed to be effective citizens and members of a community_critical thinking, analytical skills, communication skills, problem solving skills, comfort with risk, active listening skills, learning skills, persistence, moral judgment skills, team building skills, [and] pattern recognition skills.

Third (and least common), the responses saw students as moral, critical, and socially aware change agents, particularly related to issues of social justice. A representative example is: "[Students] will be change agents, be socially and morally aware, take critical action, . . . [be] aware of and sensitive to issues of social justice and have the confidence and skills to make a positive difference."

While exploring the different ways of defining and conceptualizing leadership in the literature would be a major piece of scholarly work on its own, it is critical to explore some of the ways in which leadership is understood in the context of higher education. When asked to consider one's vision of leadership, it is often difficult to disassociate the concept of leadership from the individual conception of the positional leader - a person with some form of title or in a position of authority in some way (Komives et al., 2007). An emphasis on positional leaders frequently promotes a passive approach to followers, and emphasizes a traditional, hierarchical, command-and-control approach to leadership.

Within the leadership studies literature, there have been three common approaches to exploring leadership (Alvesson \& Spicer, 2012; Wagner \& Pigza, 2016). The first is a functionalist approach, where leadership is understood as a stable object of study, with a focus on exploring the traits correlated with leadership or different task-centric or peoplecentric leadership behaviours (including formulating visions or transforming followers). The second is an interpretivist approach, where leadership is understood as a socially constructed phenomenon developed through processes of inter-subjective and value-laden understandings 
and interpretations, the study of which is aimed at increasing shared meaning. And the third is a critical approach, where leadership is not just understood as being socially constructed, but also as a domain influenced by patterns of power and domination subject to broader ideological and institutional conditions (Alvesson \& Spicer, 2012).

There are a few leadership models that have had a significant influence on the development of leadership education within universities and colleges. Kouzes and Posner (2007), for example, argue that "good leadership is an understandable and universal process" (p. xiii). They go on to argue that there are "shared patterns to the practice of leadership. And these practices can be learned" in the context of higher education (p. xiii). The authors spend a significant majority of their work focused on the characteristics of admired leaders and how individual leaders interact with and motivate those they are working with. By articulating what they call the "practices" for great leaders, Kouzes and Posner (2007) argue that "[i]t's not the absence of leadership potential that inhibits the development of more leaders, it's the persistence of the myth that leadership can't be learned. . . . It's our collective task to liberate the leader in each and every one of us" (p. 340-41).

"Transformational leadership" is another common way of conceptualizing leadership. Denning (2007) describes transformational leadership as that which is focused on:

- Changing the world by generating enduring enthusiasm for a common cause

- Presenting innovative solutions to solve significant problems

- Catalyzing shifts in values and ideologies

- Demonstrating willingness to sacrifice personal interests

- Helping others get through critical moments of crisis

- Inspiring people to want change

- Recognizing the importance of the followers becoming the next leaders

The literature on transformational leadership usually implies or assumes a moral purpose, often related to order, equality, liberty, freedom, and justice, but rarely makes such purposes explicit (Komives et al., 2007).

Many of the global challenges facing our society, which higher education graduates will grapple with over their lifetimes, require a social justice orientation. Indeed, the Association of American Colleges and Universities (2002) articulated just such a vision of higher education fifteen years ago:

[]nstitutions should foster intellectual honesty, responsibility for society's moral health and for social justice, active participation as a citizen of a diverse democracy, discernment of the ethical consequences of decisions and action, and a deep understanding of one's self and respect for the complex identities of others, their histories and their cultures. (p. xii)

If higher education institutions are truly interested in moving forward with an agenda of educating "leaders of tomorrow," then we must explore how we might move beyond these 
two functionalist conceptualizations of leadership in higher education.

Ryan's (2006) vision of critical, emancipatory, and inclusive leadership, for example, argues that leadership needs to be re-conceptualized as an intentionally inclusive practice that values individuals and communities without prejudice based on culture, race, ethnicity, gender, sexual orientation, or any other form of discrimination experienced in society. Inclusive leadership is based on critical and emancipatory notions that everyone is included, not just in educational processes, but in all social, cultural, economic and political institutions. In this conceptualization, leaders must embrace inclusive practices in all aspects of work and life and ensure that they are not unintentionally being exclusionary. ${ }^{2}$

To make inclusive leadership work in the context of higher education involves making inclusion a non-negotiable reality. In doing so, we create a sense of urgency about inclusion that ensures as much as possible exclusive practices are exposed and mitigated, from pre-admission to convocation and beyond, and from first-year students to senior administrators. An inclusive leadership model for higher education would involve educating participants (students, staff, and faculty) about roles and responsibilities in inclusive leadership processes in all disciplines, developing a critical consciousness about inclusion in society (that confronts, for example, the reality of who is privileged to attend institutions of higher learning), developing the complementary attributes that make inclusive leadership possible (empathy, communication, ethical and social understanding), and promoting dialogue and adopting inclusive processes at the institution and beyond (Ryan, 2006).

A similar way of conceptualizing leadership is articulated by Komives et al. (2007) as a relational model of leadership_-where leadership is defined as "a relational and ethical process of people coming together attempting to accomplish positive change" (p. 29). This relational model of leadership is purposeful, inclusive, empowering, ethical, and process-oriented. It ties the inclusive and critical nature of Ryan's model to a sense of leadership for a social justice purpose, as well as to a sense of how the individual can function as a change agent within an organization or society (Komives et al., 2007; Ryan, 2006). It is critical that higher education institutions conceptualize leadership as an outcome of higher education in the context of relational and ethical practices that foster positive change, and the attributes that enable such an inclusive model of leadership ought to be the focus of academic programs across the disciplines.

So how do we best mobilize a campus community around developing leadership attributes that foster an inclusive, relational leadership practice? The University of Alberta, where I am an alumnus, is just one of a few thousand universities in North America alone, and has over 275,000 living alumni. Are they all leaders, or are there only a select few? Looking at the entire group of living alumni at that one institution, has the institution failed or succeeded

\footnotetext{
${ }^{2}$ Of course, there are important nuances within the term "inclusion" and limitations to the use of inclusion as an institutional goal. Inclusive leadership must still anchor itself in a critical interrogation of the structural reasons underlying inequality and injustice, and it must remain attentive to how the value of inclusion is legitimately contested. Jordan Sifeldeen (this issue), for example, cautions against the idea of inclusivity, seeing it as a mechanism for normalizing or "tolerating" difference.
} 
to deliver on a belief that they educate "leaders of tomorrow"? How would one evaluate it? How would academic programs need to change? What about individual courses? What is the most appropriate pedagogy for engaging in this type of learning? How do universities provide students opportunities to develop leadership skills, and to engage as leaders in their community?

Much like the literature on undergraduate research and inquiry argues that research and inquiry skills are graduate attributes all students should develop across all disciplines, it can be argued that leadership attributes are equally important for all students across higher education (Healey \& Jenkins, 2009; Wuetherick \& McLaughlin, 2011). To achieve this aim, institutions need to focus on pedagogical and curricular approaches known to develop leadership attributes. The intersectionality of leadership development and service-learning is well-developed in the literature (Mayhew \& DeLuca Fernandez, 2007; Owen, 2016; Seemiller, 2016; Wagner \& Pigza, 2016). It has been argued that "the theory and practice of leadership and of servicelearning share common elements that make service-learning a fitting pedagogical choice for those who teach and facilitate leadership education" (Wagner \& Pigza, 2016, p. 11). When leadership attributes are framed with a social justice orientation, Wagner \& Pigza (2016) argue that we must take an approach to service-learning grounded in six critical values: awareness of context, reciprocal participation, critical examination of power and privilege, reflective practices, sustained engagement, and a commitment to change and justice. Indeed, critical reflection has been identified as the key differentiator for moving from a service to a social justice paradigm in leadership education, which enables a move towards critical discourse and action (Owen, 2016). Therefore, I argue for an activist pedagogical approach to higher education, grounded in critical community service-learning, as an important component of developing inclusive, relational leadership attributes for all students across all disciplines.

\section{Activist Pedagogy}

Before we further explore how we might embed leadership as a graduate attribute through activist pedagogical approaches, it is important to unpack what is meant by activist pedagogy. While that term - activist pedagogy-has been used in educational literature for a number of years, there is some variability in the ways activist pedagogy is applied, due primarily to the variability in how people conceptualize the word "activist" or "activism." Building on those various conceptualizations, I define activism as the use of direct action to achieve a (political, economic, cultural, or social) goal. Such a definition of activism complements a definition of leadership as a relational and ethical process seeking positive change. This allows us to envision a way in which instructors might encourage students to identify projects through which they can tap into their disciplinary course content, as well as the general and discipline-specific attributes they are developing through their learning experiences, to seek positive change in the world (Bickford \& Reynolds, 2002). Indeed, 'by exploring students' rationales for activism projects, we might also help students to recognize and claim their own assumptions and ideologies" (Bickford \& Reynolds, p. 245). Fisher (2009) argues further that activism is healthiest when it embraces its diversity - when a variety of individuals and organizations come together over 
the same problem from a variety of angles.

While there are a variety of ways in which such a pedagogical approach might manifest, one approach that might prove particularly effective at embracing such an activist approach to developing leadership is critical community service-learning (CSL). An activist CSL approach can result in powerful experiences where students collectively engage in solving communityidentified social problems at a systemic level, with the intention of challenging students to develop an understanding of the structural and systemic forces that shape social environments, while assuming an "activist-orientation" to addressing said problems (Britt, 2009). Adopting a broad definition of activism allows a greater diversity of student perspectives to engage, but also raises some challenges for academics. We must resist the impulse to criticize student activists who might share our goals, but use different tactics, or might not share our goals (Fisher, 2009). This influences how academics might assess student work, and in particular, points to the importance of student self-reflection (of experiences, as well as assumptions and values underpinning those experiences).

\section{Roots of activist pedagogy in community service-learning}

Community service-learning has been seen as an increasingly important way to overcome the barrier (real or perceived) between higher education institutions and community (Speck, 2001). Building upon the progressive educational philosophy of Dewey (and others), servicelearning, along with other forms of experiential learning, provides opportunities for students to gain practical experience employing the knowledge and skills they develop through their post-secondary education. For Dewey, pedagogy and epistemology were related, and his theory of knowledge related to and derived from his notions of citizenship and democracy (Giles \& Eyler, 1994). Experiential learning opportunities, such as CSL, involve a continuous reflective cycle, where students engage in abstract conceptualization, active experimentation, concrete experience, and reflective observation (Kolb, 1984). This cycle is similar to Dewey's notion of liberal praxis where students move through the cycle of suggestion, intellectualization, hypothesis generation, reasoning, and testing the hypothesis in action (Giles \& Eyler, 1994).

In particular, CSL is seen as a significant way to improve students' skill development, as well as sense of civic responsibility (Speck, 2001; Britt, 2009). There have been many explorations of how CSL can be implemented across the disciplines, and that demonstrate the impact that CSL can have on student learning (Howard, 2001; Schoenfeld, 2004; Speck, 2001;). Unfortunately, it is possible for CSL to focus solely on the learner's own development through volunteerism, rather than on a bi-directional development of both the individual student and the community. These "traditional" CSL experiences, as they have been termed in the literature, can be highly problematic when students (and the faculty facilitating the CSL experiences) ignore the structural reasons underlining inequality and injustice (Bickford \& Reynolds, 2002; Butin, 2003; Mitchell, 2008). They can also entrench social and cultural biases by reinforcing "otherness" and the presumption of knowledge that can be more damaging than ignorance (Bickford \& Reynolds, 2002).

Activist approaches to community service-learning transcend the progressivist notions of 
civic engagement and responsibility and move towards tackling systemic social problems by encouraging students to explore the problems' root causes as well as how their own actions can contribute to overcoming those social problems. They move towards what Butin (2003) calls political and anti-foundational service-learning. In political conceptualizations of servicelearning, "issues are manifest through power (im)balances, questions of legitimacy, allowed or silenced perspectives, and negotiations over neutrality/objectivity" (p. 1681), while in antifoundational (or post-structural) conceptualizations, the service-learning experience acts as a "site of identity construction, destruction, and reconstruction" where learners are "concerned with how an innovation constructs, reinforces, or disrupts particular unarticulated societal norms of being and thinking" (p. 1683-84).

\section{Activist pedagogies' roots in critical pedagogy}

Activist pedagogies, and activist approaches to community service-learning, also have their roots in the intellectual tradition of critical pedagogy (Grace, 2006). Critical pedagogy argues for education to be focused on raising the critical consciousness of society (Freire, 2008; Giroux, 2009) and mobilizing action to address the systemic, root causes of social problems. The teaching and learning environment then becomes even more inter-connected with how we guide students' identity formation within an explicitly social context, a process of discovery connected to the struggle against injustice (Fassbinder, 2007).

Critical pedagogies retain the dialectical relationship between theory and practice (Giroux, 2009). They are rooted in the notion of critical praxis, whereby individuals/organizations engage in action, critical reflection, and further critical action to address social problems facing society (Grace, 2006). They are rooted in notions of social justice as well as self and social empowerment, and acknowledge that all knowledge is socially constructed and politically contrived (Grace, 2006). Through critical pedagogies, we also gain a sense "of the consequences for teaching practice, curriculum and program development, educational policy formation, and social learning processes" (Collins, 2006, p. 121).

Critical pedagogies manifest in community service-learning as a counter to traditional, volunteerism-oriented CSL. Mitchell (2008), for example, articulates a vision of "critical community service-learning" where students adopt a social change orientation while working to redistribute power and develop authentic relationships in and with community. She argues that " [c]ritical service-learning pedagogy fosters a critical consciousness, allowing students to combine action and reflection in classroom and community to examine both the historical precedents of the social problems addressed in their service placements and the impact of their personal action/inaction in maintaining and transforming those problems" (p. 54).

Activist pedagogies that embrace a critical praxis_-of critical action and reflection-can help avoid what has been termed "mindless activism" (Collins, 2006). Elias and Merriam (1980) argue that "theory without practice leads to an empty idealism, and action without philosophical reflection leads to mindless activism" (p. 4). There are cases where activists (whether in the context of CSL opportunities or not) have mobilized to action without taking the time to think strategically and tactically about how to ensure the community's needs 
inform the intended outcome of the action, as well as how the community mobilizes behind the action taken. For example, in a CSL context, students might develop a well-meaning plan to raise awareness of a community issue or need (e.g., refugees coming in large numbers to a community), without understanding the potential backlash to the community that might arise from broader societal misunderstandings of the socio-cultural contexts of that issue (e.g., the readiness of the broader community to address the issue, and the potentially negative and/or violent responses by groups within the community at large).

Effective activist pedagogies work towards helping students think strategically about the development of activist strategies for instigating positive action and change. This can manifest, for example, in students developing and engaging in inclusive and relational leadership processes with and for the community. Examples of effective approaches to activism can be found in Shaw's The Activist's Handbook (2013), which argues for a tactical activism where the community's historical and socio-cultural dynamics are well-understood, thus maximizing the potential for greater economic and social justice. Activist pedagogies, rooted in a critical philosophical framework, ensure that action is not privileged over critical thought, "or localized events over a critical understanding of the totality of conditions within which they operate" (Collins, 2006, p. 125).

\section{Advancing activist community service-learning}

Activist community service-learning can be an extremely powerful pedagogical approach in higher education, particularly as it relates to the development of leadership attributes. By combining the beneficial educational impacts of experiential and reflective learning with the development of a critical consciousness (particularly as informed by the needs and perspectives of community), activist CSL allows us to unpack the systemic roots of social problems and move towards positive and lasting social change. It is crucial to facilitate students' reflection about their experiences, what they have learned about themselves and the situations experienced, the role of their own assumptions and values, and the systemic causes of the social issues with which they were involved. Students should be encouraged to translate their values into politically and/or socially-oriented action (Hedley, 2004).

This form of participatory learning can result in the validation of personal experience and the development of individual confidence, the development of socio-political knowledge and an understanding of the place of activism, and the development of critical thinking and open-mindedness (Stake \& Hofmann, 2001). In this sense, activist pedagogies can work by guiding students to make connections between course material and the political/social context within which it is embedded, and by helping students to recognize how they can become active agents for positive political and social change (i.e., "leaders of tomorrow") (Stake \& Hofmann, 2001). Community service-learning, as an activist pedagogy, must strive for a balance between discipline-related outcomes and activism, critical consciousness, or social change-oriented outcomes, thereby avoiding what might be called the binary of service vs. activism-where community service is considered a laudable act but activism is perceived with negative connotations (Bickford \& Reynolds, 2002). Bickford and Reynolds (2002) argue for a nuanced 
understanding of CSL that embraces its activist potential, even in light of preconceived (and often negative) connotations of activism amongst some students and instructors that may serve as a barrier to its introduction within a program or institution.

One of the biggest problems identified by academics implementing activist pedagogies is student resistance, particularly because of this perceived binary of service and activism. Several writers have commented on the profound discomfort felt by many students (and other academics) with activism, even while notions of advocacy, service, and civic engagement are embraced (Bickford \& Reynolds, 2002; Fixmer-Orain et al., 2009). The determinant for students' successful engagement with and for community through activist pedagogies may be in how they conceptualize activism. If we take a broader definition of activism (discussed above) that allows students to see themselves as activists already working for positive change in society, and if we emphasize that they can choose to be activists related to issues that connect to their personal/scholarly interests and values, as well as to their ongoing development of leadership attributes, then we can encourage a broader range of students to embrace activist pedagogies.

Activist pedagogies face a few key barriers to effective implementation, including the increasingly pervasive experience of students as consumers (Morley, 2003); active or passive student resistance arising from students' inability or unwillingness to engage in the critical reflection necessary to transform their experiences into meaningful and authentic learning (Jones et al., 2005); or neoliberal pressures associated with higher education as a preparatory site for work (Barnett, 1990). Faculty play a key role in helping students broaden their understanding of what activism might include. Astin (1993), for example, found that on campuses where faculty stated that a goal of their institution was to promote student social activism, more positive change was seen in students' interest in, and valuing of, activism. The emphasis placed by faculty on various social issues, particularly in the context of the curriculum, influences student attitudes.

\section{Interlude: Modeling the Activist Life}

It is essential to acknowledge the importance of faculty modeling the activist life, especially considering the impact faculty attitudes and actions can have on students. There is an understanding that being an activist academic can result in constant critique from peers, particularly arising from neoliberal pressures placed on academics to "perform" as defined by specific institutional criteria related to faculty evaluation (Cushman, 1999; Derber, 2005; Fisher, 2009; Hay 2001). Performative pressures placed on academics have a serious impact on academic's choices related to "risky" and innovative practices in research, teaching, and service (Ball, 2003). Harland et al. (2010) explore how neoliberal pressures impact the ability of academics to serve as the critic and conscience of society, and in particular how academics enable society at large to be their own critic and conscience.

It has long been argued that academics not give society lessons in morals, even as it is recognized that how they conduct themselves and live their academic values has social implications (Dewey, 1916). Cushman (1999), drawing heavily on Bourdieu, argues that the 
"public intellectual" plays a dual and dueling role as part of an autonomous intellectual world as well as in political action informed by the competence and authority acquired within their intellectual field. Being an activist academic does not mean that academics indoctrinate students into their own ideology. Faculty who prepare students for social and political action need not proselytize, but they rather foreground action by what might be described as "problem-posing education" (Fassbinder, 2007). Derber (2005), for example, argues:

\begin{abstract}
The positivist tradition suggests teachers must be objective and are morally obliged not to become preachers, ideologues, or political activists in the classroom. The normative tradition suggests teaching is inevitably value-laden, and that in an increasingly unjust and violent world, teachers have an obligation to help students connect knowledge with action. I have long been in the second camp, but I depart radically from the view that professors should preach or indoctrinate. The best way to practice normative teaching is to recognize that students are most likely to act with enduring commitment in the world when they decide for themselves whether and how to translate critical thought into activism. (p.1)
\end{abstract}

This observation ties into the dual tension universities face, as sites of both contestation and compliance-serving social/economic/political needs and perpetuating the norms of individual disciplines, while also critiquing existing knowledge and contesting the assumptions and the social forces that shape ways of thinking (Rowland, 2003). Rowland (2003) argues that "it is through reason, careful observation, and critical analysis that universities (through their academic and student bodies) contribute to freeing society from forces of unreason and prejudice" (p. 15). This suggests an academic community that is active, critical, reflective, and imaginative, whose contribution is acknowledged to be open to question different interpretations, including from the broader community beyond the academy (Rowland, 2003). Giroux argues that this type of activist pedagogical practice will make our jobs harder and more uncomfortable, which will impact how individual academics negotiate the performative pressures our institutions place on us (Giroux, 2009; Hay, 2001).

\title{
Conclusion: Embracing Activist Pedagogies in to Develop Leadership Attributes
}

Komives et al. (2007) explore different ways in which leadership attributes might be developed on campus, as well as some of the barriers that may impact success in this endeavour. Developing student leaders across the disciplines can be facilitated institutionally when students are viewed as major stakeholders in their learning, and when students are viewed as partners and change agents (Cook-Sather, Bovill, \& Felten 2014; Kay, Dunne, \& Hitchinson 2010). It is also facilitated when faculty are the stewards of the institution, when everyone in the institution contributes directly to student development, when there is an institutional recognition that change initiatives can start with anyone, and when there is a recognition that we make change through collective action (Komives et al., 2007). Such collective action is particularly powerful when facilitated through activist CSL that meaningfully engages community in determining the change sought from that action and defining the way in which relational and inclusive 
leadership attributes and practices might be developed. Komives et al. (2007) further identify that there are a number of internal beliefs within higher education that constrain the ability to develop leadership among the student body, including the following perceptions:

- that the campus doesn't care about students;

- that students do not have enough experience to lead major campus-change efforts;

- that faculty expertise is not valued in running the institution;

- that nothing can be changed because of administrative attitudes;

- that faculty and administration could never work together; and

- that all learning occurs in the classroom.

A move towards a more activist pedagogy, which in turn provides better opportunities for students to engage in reflective practice both in their disciplinary learning as well as in their development of leadership attributes, can result in a profound transformation of the type of educational experience available to students in higher education. This can have significant consequences on their preparedness for the world in which they will find themselves upon graduation. Possible barriers to using activist pedagogies in higher education can be overcome by conceptualizing activism broadly in a manner that focuses on positive social change and makes it inclusive for all students. Even then, we might still need to address any potentially negative connotations students might have regarding what is meant by activism, as well as limitations arising from potentially narrow conceptions of leadership. It is not only possible to have, but important to provide, experiences that go far beyond traditional volunteerism and service "to" community, where students instead participate in activist CSL opportunities that meaningfully engage "with" and "for" community with the goal of both positive social change and the development of students' leadership attributes.

\section{About the Author}

Brad Wuetherick is the Executive Director, Learning and Teaching in the Office of the Provost and VP Academic, and Centre for Learning and Teaching, at Dalhousie University. Of Métis and European ancestry, Brad's research focuses broadly on advancing evidencebased practices in higher education teaching and learning. Email: Brad.Wuetherick@dal.ca 


\section{References}

Alvesson, M., \& Spicer, A. (2012). Critical Leadership Studies: The case for critical performativity. Human Relations, 65(3), 367-390.

Astin, S. (1993). What matters in college? Four critical years revisited. San Francisco, CA: Jossey-Bass. Association of American Colleges and Universities (2002). Greater Expectations: A new vision for learning as a nation goes to college. Washington, DC: Association of American Colleges and Universities.

Ball, S. (2003). The teacher's soul and the terrors of performativity. Journal of Education Policy. 18(2), 215-228.

Barnett, R. (1990). The Idea of Higher Education. London, England: SRHE/Open University Press.

Barnett, R. (2000). Realizing the University in an age of Supercomplexity. London, England: SRHE/Open University Press.

Barnett, R. (2010). Being a University. New York, NY: Routledge.

Bickford, D., \& Reynolds, N. (2002). Activism and service-learning: Reframing volunteerism as acts of dissent. Pedagogy: Critical Approaches to Teaching Literature, Language, Composition and Culture. 2(2), 229-252.

Britt, L. (2009). Developing students as learners, citizens and activists: A proposed taxonomy of service-learning approaches. Presented at Conference on Service-Learning and Civic Engagement. Institute for Ethical and Civic Engagement. Boulder, CO. October 2009.

Brookfield, S. (2003). Putting the critical back into critical pedagogy: A commentary on the path of dissent. Journal of Transformative Education. 1(2), 141-149.

Butin, D. (2003). Of what use is it? Multiple conceptualizations of service-learning within education. Teachers College Record, 105(9), 1674-1692.

Collins, M. (2006). The critical legacy: Adult education against the claims of capital. In T. Fenwick, T. Nesbit, \& B. Spencer (Eds.), Contexts of Adult Education: A Canadian Perspectives (pp. 118-127). Toronto, ON: Thompson Educational Publishing Inc.

Cook-Sather, A., Bovill, C., \& Felten, P. (2014). Engaging students as partners in learning and teaching: A guide for faculty. San Francisco, CA: Jossey-Bass.

Cushman, E. (1999). The public intellectual, service, and activist research. College English, 61(3), 328336.

Denning, S. (2007). The secret language of leadership. San Francisco, CA: John Wiley and Sons.

Dewey, J. (1916). Democracy and education. New York, NY: MacMillan.

Dewey, J., (1963). Experience \& education. New York, NY: Collier Books.

Elias, J. L., \& Merriam, S. (1980). Philosophical foundations of adult education. Malabar, FL: Robert E. Krieger.

Fassbinder, S. (2007). An expanded definition of "pedagogy": An essay review. Education Review, 10(11).

Fisher, A. (2009). Composting the tribulations of activism in academia. Rocky Mountain Communication Review. 6(2), 42-46.

Fixmer-Oraiz, N., \& Murray, B. (2009). Challenging pedagogies: Reflections on communication activism and service-learning. Rocky Mountain Communication Review. 6(2), 52-55.

Freire, P. (1970). Pedagogy of the oppressed. New York, NY: The Seabury Press.

Freire, P. (2008). Education for critical consciousness. New York, NY: Continuum. 
Giles, D., \& Eyler, J. (1994). The theoretical roots of service-learning in John Dewey: Toward a theory of service-learning. Michigan Journal of Community Service Learning, 1(1), 77-85.

Giroux, H. (2009). Critical theory and educational practice. In A. Darder, M. Baltodano, \& R. Torres (Eds.), The Critical Pedagogy Reader. New York, NY: Routledge.

Grace, A. (2006). Critical adult education: Engaging the social in theory and practice. In T. Fenwick, T. Nesbit, \& B. Spencer (Eds.), Contexts of Adult Education: Canadian Perspectives. Toronto, ON: Thompson Educational Publishing Inc.

Harland, T., Tidswell, T., Everett, D., Hale,L., \& Pickering, N. (2010). Neoliberalism and the academic as critic and conscience of society. Teaching in Higher Education, 15(1), 85-96.

Hay, I. (2001). Critical geography and activism in higher education. Journal of Geography in Higher Education, 25(2), 141-146.

Healey, M. \& Jenkins, A. (2009). Undergraduate research and inquiry. York: UK: Higher Education Academy.

Hedley, M. (2004). Implementing activist-oriented internships in Sociology: Training the next generation of activists. Presented at the American Sociological Association conference. San Francisco, CA, August 14-17.

Howard, J. (2001). Service-learning course design workbook - Companion volume. Michigan Journal of Community Service Learning. The University of Michigan: OCSL Press.

Jones, S., Gilbride-Brown, J., \& Gasiorski, A. (2005). Getting inside the "underside" of servicelearning: Student resistance and possibilities. In D. Butin (Ed.), Service Learning in Higher Education (pp. 3-24). New York, NY: Palgrave MacMillan.

Kay, J., Dunne, E., \& Hutchinson, J. (2010). Rethinking the values of higher education - students as change agents? Gloucester, UK: The Quality Assurance Agency for Higher Education.

Kolb, D. (1984). Experiential learning. Englewood Cliffs, NJ: Prentice-Hall.

Komives, S., Lucas, N., \& McMahon, T. (2007). Exploring leadership. San Francisco, CA: Jossey-Bass.

Kouzes, J., \& Posner, B. (2007). The leadership challenge. San Francisco, CA: Jossey-Bass.

Kouzes, J., \& Posner, B. (2008). The student leadership challenge. San Francisco, CA: Jossey-Bass.

Mayhew, M., \& DeLuca Fernandez, S. (2007). Pedagogical Practices That Contribute to Social Justice Outcomes. The Review of Higher Education, 31(1), 55-80.

Mitchell, T. (2008). Traditional vs. critical service-learning: Engaging the literature to differentiate two models. Michigan Journal of Community Service Learning, 14(2), 50-65.

Morley, L. (2003). Quality and power in higher education. Maidenhead, England: SRHE and Open University Press.

Owen, J. (2016). Fostering critical reflection: Moving from a service to a social justice paradigm. New Directions for Student Leadership, 150 (Summer), 37-48.

Rowland, S. (2003). Learning to comply: Learning to contest. In J. Satterthwaite, E. Atkinson, \& K. Gale (Eds.), Discourse, power and resistance: Challenging the rhetoric of contemporary education (pp. 1326). Stoke on Trent, UK: Trentham Books.

Ryan, J. (2006). Inclusive leadership. San Francisco, CA: Jossey-Bass.

Schoenfeld, R. (2004). Service-learning - Guide \& journal. Seattle, WA: Guide and Journal Publications of ServiceLearningHigherEd.com.

Seemiller, C. (2016). Complementary learning objectives: The common competencies of leadership and service-learning. New Directions for Student Leadership, 150 (Summer), 23-35. 
Shaw, R. (2013). The activist's handbook: Winning social change in the $21^{\text {st }}$ Century (2 ${ }^{\text {nd }}$ ed.). Berkeley, CA: University of California Press.

Speck, B. (2001). Why service learning? New Directions for Higher Education, 114, 3-13.

Stake, J., \& Hoffman, F. (2001). Changes in student social attitudes, activism, and personal confidence in higher education: The role of Women's Studies. American Educational Research Journal, 38 , 411-436.

Wagner, W., \& Pigza, J. (2016). The Intersectionality of Leadership and Service-Learning: A $21^{\text {st }}$ Century Perspective. New Directions for Student Leadership, 150 (Summer), 11-22.

Wuetherick, B. (2007). Educating leaders of tomorrow, but leaders of what? Presentation at Society for Teaching and Learning in Higher Education, Windsor, ON, June 2007.

Wuetherick, B., \& McLaughlin, L. (2011). Students' perceptions of the learning environment: A partnership to enhance our understanding of the undergraduate experience. In S. Little (Ed.), Staff-student partnerships in higher education (pp. 185-200). London, UK: Continuum International Publishing Group. 